\title{
PENDEKATAN BISNIS BUMDES BERKEMAJUAN DI KONDISI WABAH PANDEMI COVID'19
}

\author{
Vembri Aulia Rahmi \\ Universitas Muhammadiyah Gresik \\ vembriaulia@umg.ac.id \\ Mohammad Zainuddin Fathoni \\ Universitas Muhammadiyah Gresik \\ zainuddin@umg.ac.id \\ Hadi Ismanto \\ Universitas Muhammadiyah Gresik \\ hadi_ismanto@umg.ac.id
}

\begin{abstract}
The impact of the Covid'19 pandemic outbreak rocked almost more than half of the world economy. In fact, many large world-class companies have suffered losses. This study seeks to describe the survival capacity of village economic institutions in supporting the economic welfare of small entrepreneurs during the pandemic that hit the country. Qualitative descriptive is used as the method of this research. The results of the study explain that BUMDes are able to survive in running the economy during a pandemic through certain business approaches, such as: changing the marketing method for village products, designing new business strategies, arousing entrepreneurial spirit, and improving service quality. Thus it can be concluded that BUMDes was able to anticipate problems in business management during the Covid'19 pandemic.
\end{abstract}

Keywords: Covid'19 Pandemic, Business, Advanced Village Enterprises Unit

\section{PENDAHULUAN}

Hingga kini belum dapat diprediksi kapan berakhirnya masa pandemi wabah Covid'19 di Indonesia, tetapi perekonomian makro begitu terkena dampak, seperti jumlah penurunan pendapatan, peningkatan pengangguran, serta bertambahnya nilai pinjaman. Akibat wabah corona, sektor riil, khususnya UMKM mengalami kelesuan ekonomi, karena penurunan permintaan barang, sementara di sektor perbankan, para investor berlomba menarik simpanan. Kondisi sedemikian didasarkan atas laporan perekonomian Jawa Timur dari Bank Indonesia yang mengungkapkan bahwa kinerja ekonomi Jawa Timur mengalami perlambatan pertumbuhan. Pemicu atas pelambatan ekonomi ditinjau dari sisi permintaan adalah karena penurunan kinerja konsumsi dan nilai ekspor, sementara dari sisi penawaran dipengaruhi oleh melambatnya lapang usaha,baik dari sektor industri pengolahan, perdagangan dan pertanian.
Pemerintah berpikir keras bagaimana menciptakan kebijakan seimbang antara penyelamatan kesehatan ataukah penanganan darurat perekonomian. Penyediaan alternatif insentif untuk menopang ketidakseimbangan situasi di masyarakat tidak serta merta mampu mengatasi permasalahan ekonomi secara instan. Bahkan pemberian bantuan pemerintah berupa dana BLT (Bantuan Langsung Tunai) juga belum dapat memperbaiki kualitas standar masyarakat. Seandainya dapat dianalogikan bahwa jika perekonomian negara sedang mengalami krisis dan mempengaruhi pendapatan perusahaan besar kelas dunia, tentunya UMKM lebih pasti akan mengalami gulung tikar (Thaha, 2020).

Kondisi tidaklah semua mengalami hal demikian, masih terdapat temuan di beberapa situasi negara justru menyatakan UMKM mampu bangkit di tengah badai krisis ekonomi (Scarborough, 2015). Penelitian ini menyoroti bagaimana UMKM di wilayah desa mampu menjalankan roda perekonomian di kala saat masa pandemi Covid'19. Demi mempersempit sasaran penelitian dan memperdalam analisis 
tentang pembahasan perekonomian desa, berikut juga kesejahteraan masyarakatnya (Zulkarnaen, 2016), maka arah penelitian ini memfokuskan pada pendekatan bisnis pada BUMDes. Kesejahteraan desa juga tidak terlepas dari dukungan BUMDes sebagai lembaga sosial sekaligus lembaga ekonomi desa (Brawijaya, 2007).

Kebijakan pemerintah terhadap wabah pandemi menyebabkan beberapa lokasi harus mengalami lock down, physical distancing, work from home, sampai PSBB, sehingga menimbulkan banyak keterbatasan akses, gerak dan aktivitas, termasuk juga transaksi ekonomi yang mempengaruhi siklus arus kas. Meskipun beberapa keadaan mengalami hambatan juga terkendala situasi, namun pelaku ekonomi tetap fleksibel mengubah cara dan metode agar mampu menyesuaikan kondisi agar kesejahteraan ekonomi tetap stabil di tengah menghadapi pandemi. Penelitian ini mencoba untuk membandingkan kinerja ekonomi Jawa Timur dibandingkan daerah lain secara nasional yang masih lebih baik kinerja ekonominya, walaupun tingkat pertumbuhan ekonomi melambat akibat terdampak wabah Covid'19, menurut data BPS Tahun 2020

Permasalahan menjadi menarik untuk dianalisis pada penelitian ini, karena meski daerah mengalami kondisi keterbatasan gerak, akan tetapi mengapa kinerja ekonomi Jawa Timur, khususnya mampu mempertahankan kesejahteraan, dan secara nasional lebih bertahan. Tentunya terdapat beberapa faktor pendukung dari sumber daya yang mampu menopang keterpurukan ekonomi di masa pandemi. Solusi terhadap hambatan dan kendala ekonomi yang dihadapi saat pandemi dapat tercerahkan melalui pendayagunaan atas semua kepemilikan potensi sumber daya (Ainiyah \& Aprilia, 2020). Penelitian ini juga memfokuskan pada identifikasi tentang kearifan lokal desa yang mendukung ketercapaian BUMDes berkemajuan serta menganalisis bagaimana pendekatan bisnis salah satu BUMDes di Indonesia, yaitu BUMDes "Podho Joyo" di Desa Sukorejo, Kecamatan Sidayu, Kabupaten Gresik. Bagaimana BUMDes menentukan strategi usaha pada saat UMKM secara global menemui pasang surut bisnis di kala wabah pandemi akan dianalisis pada penelitian ini.

Penelitian sebelumnya pada BUMDes "Podho Joyo" di Desa Sukorejo sudah pernah dilakukan untuk mengetahui peran BUMDes sebagai lembaga ekonomi desa, di mana diperoleh informasi jika BUMDes memiliki tata kelola manajemen yang cukup baik dengan pencapaian atas prestasi di tingkat Propinsi Jawa Timur dan juga Kabupaten Gresik sebagai BUMDes terbaik pada Tahun 2016. Sementara lain, penelitian ini akan menganalisis pendekatan bisnis oleh BUMDes berkemajuan saat kondisi sedang mengalami pandemi. Tujuan penelitian ini akan mendiskripsikan bagaimana upaya BUMDes "Podho Joyo" menciptakan pendekatan bisnis untuk bertahan selama pandemi Covid'19. Selain itu penelitian juga akan menjelaskan bagaimana strategi kewirausahaan desa dalam membangkitkan kesejahteraan ekonomi bagi masyarakat desa.

\section{TINJAUAN PUSTAKA}

Pada umumnya, wabah pandemi Covid'19 melumpuhkan ekonomi masyarakat, karena penurunan tingkat konsumsi dan menurunnya jumlah pendapatan. Dalam rangka menyesuaikan antara kebijakan pemerintah dan keadaan riil di lapangan, maka stakeholder mengupayakan solusi untuk menyeimbangkan aliran kas, sehingga bermanfaat meminimalkan dampak krisis. Solusi yang dapat dilakukan oleh BUMDes, antara lain dengan mengoptimalkan potensi desa. Pemberdayaan potensi desa dapat dilakukan dengan mengeksplorasi kearifan lokal, dan pengelolaannya sebagai keunggulan desa melalui pendekatan bisnis.

BUMDes berkemajuan tidak hanya dinilai atas tata kelola administratif (Nilawati, 2018), tetapi kemampuan mengelola bisnis, karena keuntungan bisnis BUMDes adalah peluang bagi kenaikan nilai PAD (Pendapatan Asli Daerah) bersumber untuk desa (Budiono, 2015) dan dapat mendukung kesejahteraan ekonomi (Anggraeni, 2016). Temuan di lapangan mengemukakan bahwa bermunculan BUMDes terbentuk di Indonesia, akan tetapi keberadaannya tidak berkembang (Ramadana, 2013) (Ainiyah \& Aprilia, 2020), karena pendapatan dari bisnis BUMDes kurang menghasilkan keuntungan. Potensi kemajuan BUMDes juga dipengaruhi oleh pengembangan dari beberapan pendekatan bisnis yang dijalankan. Selama pendekatan bisnis BUMDes masih lemah, maka BUMDes masih menjalankan satu peran saja, yaitu sebagai 
lembaga sosial untuk desa, sedangkan fungsi BUMDes adalah menjalankan peran sosial dan peran komersial (Brawijaya, 2007).

$$
\text { Pendekatan Bisnis BUMDes }
$$

dioptimalisasi dari unit bisnis BUMDes dan meliputi semua unit usaha milik lembaga yang disediakan untuk memenuhi kebutuhan masyarakat desa. Kearifan lokal desa sebagai potensi yang diberdayakan dalam pendekatan bisnis desa. Upaya menganalisis pendekatan bisnis BUMDes dapat dilakukan dengan menganalisis proses arsitektur model bisnis atau disebut kerangka klasifikasi proses, baik proses operasional maupun sumberdaya manusianya (Purabaya, Pradnyana, \& Wahyono, 2020). BUMDes adakalanya membutuhkan pendekatan bisnis seperti menjalin kemitraan dengan pihak eksternal jika terdapat keterbatasan atas potensi desa, namun merupakan kewajibannya untuk memenuhi kebutuhan masyarakat (Mulatsih \& Purnamadewi, 2020).

Metode pengembangan BUMDes berkemajuan melalui pendekatan bisnis membutuhkan faktor - faktor pendukung yang mampu memperbaiki kinerja BUMDes. Sementara kinerja BUMDes dipengaruhi oleh strategi pemberdayaan BUMDes (Hidayat \& Sulastri, 2019) yang meliputi beberapa bidang penguatan, antara lain: akuntansi, teknologi informasi, kepemimpinan, tipe bisnis. Pencapaian strategi pemberdayaan BUMDes dapat dilakukan dengan cara benchmark (tolak ukur), akreditasi, sistem penjamin mutu internal, dan evaluasi. Manajemen proses bisnis BUMDes menjabarkan beberapa tingkatan proses bisnis yang ditata menurut model kerangka klasifikasi proses, yaitu teridiri dari beberapa tingkatan proses operasi dan manajemen serta layanan pendukung (Purabaya et al., 2020). Langkah mengidentifikasi strategi bisnis BUMDes dengan cara menguraikan analisis SWOT yang dimiliki desa, seperti menentukan strategi bisnis BUMDes berada pada titik kuadran (Sumantara et al., 2019).

Strategi bisnis BUMDes sangat memungkinkan untuk mengikuti perkembangan jaman melalui pergeseran model bisnis. Model bisnis konvesional bergeser menjadi konsep bisnis modern, misalnya pergeseran paradigma pengelolaan BUMDes secara birokratik diubah dengan pengelolaan sektor bisnis dan tetap mempertimbangkan keterlibatan masyarakat desa sebagai partisipator, karena BUMDes juga merupakan bisnis sosial (Maab, Wijaya, Atika, \& Kurniasih, 2018). Beberapa unit bisnis BUMDEs yang bisa dikembangkan seperti: perdagangan, keuangan, dan unit produksi. Cara mempertahankan dan mengembangkan usaha yang sudah ada pada BUMDes adalah sama dengan strategi bisnis pada perusahaan pada umumnya, yaitu memonitor segala aktivitas bisnis, seperti: omset, laba rugi, persediaan barang, promosi, layanan dan lain lain, sedemikian halnya pada strategi bisnis BUMDes ketika merintis usaha baru yang harus dilakukan melalui riset pasar (Brawijaya, 2007).

Konsep bisnis desa pada BUMDes berkesinambungan dengan kewirausahaan sosial, karena bergerak pada BUMDes menjalankan dua peran, baik sosial maupun komersial. Kewirausahaan pada BUMDes menempatkan posisi desa dalam kemandirian usaha, yaitu menentukan seberapa besar kontribusi BUMDes terhadap perekonomian desa. Dengan demikian, mencapai BUMDes berkemajuan diawali dengan sinergitas konsep desa wirausaha, yaitu menggerakkan kewirausahaan masyarakat desa (Kusuma \& Purnasari, 2016). BUMDes didirikan dengan prinsip dari, oleh dan untuk rakyat, menjelaskan bahwa pemasok produk BUMDes berasal dari masyarakat dan juga anggota BUMDes. Oleh karena itu, untuk mampu meningkatkan keunggulan produk BUMDes juga membutuhkan peningkatan kualitas dari pemasok BUMDes atau masyarakat desa tersebut. Modal pengembangan usaha baru BUMDes melalui gerakan kewirausahaan desa dijalankan secara bersama - sama dengan elemen masyarakat desa karena secara riil di lapangan modal pembentukan lembaga dibentuk dari modal dana pemerintah dan dana masyarakat desa tersebut.

\section{METODE PENELITIAN}

Metode yang digunakan dalam penelitian ini mengikuti pola jenis penelitian Community-Based Research (CBR), yaitu penulis melakukan penelitian dengan melibatkan masyarakat, dalam hal ini adalah stakeholder BUMDes. Meskipun rancangan penelitian tidak sepenuhnya mengikuti tahapan metode CBR, tetapi paradigma penelitian mengikuti prinsip CBR (Hanafi, 2015). Keterlibatan peneliti dan masyarakat dalam 
kegiatan pengabdian masyarakat melalui kegiatan pelatihan kewirausahaan pada anggota dan pengurus BUMDes. Observasi dilakukan peneliti selama masa pandemi Covid'19. Penelitian ini juga membandingkan antara implementasi praktik bisnis sebelum dan saat masa pandemi. Pendekatan diskriptif kualitatif juga digunakan untuk memberikan gambaran kondisi riil permasalahan penelitian dengan dasar pertimbangan bahwa metode diskriptif kualitatif memiliki karakter tipe penelitian yang menggunakan data natural untuk menjelaskan sebuah kebenaran tanpa melakukan intervensi pengaturan kejadian dan juga manipulasi variabel (Nassaji, 2015).

Akurasi dan kredibilitas penelitian kualitatif dapat dilakukan dengan beberapa teknik, antara lain: trianggulasi data, member checking dan auditing. Temuan pada analisis kualitatif dapat berupa tema, pola, konsep, pandangan dan pemahaman (Raco, 2018). Sebelum melakukan wawancara terhadap informan penelitian, maka dilakukan identifikasi masalah penelitian untuk selanjutnya dilakukan pengumpulan informasi melalui observasi lapangan yang dilakukan langsung oleh peneliti. Wawancara mendalam dilakukan peneliti kepada direktur BUMDes pada awal sebelum terjadi masa pandemi. Agar memperjelas informasi dilakukan upaya trianggulasi data dan menyempurnakan kebenaran. Berikutnya, peneliti juga melakukan wawancara pada pengurus BUMDes serta masyarakat desa, selaku anggota BUMDes dalam rangka member checking. Peneliti mendiskusikan hasil penelitian kepada pihak luar yang memiliki pengetahuan dan kepakaran tentang pengelolaan BUMDes.

BUMDes "Podho Joyo" berada pada wilayah Desa Sukorejo, Kecamatan Sidayu, Kabupaten Gresik merupakan subyek pada penelitian ini. Proses pengambilan informasi untuk kebutuhan penelitian, baik data primer maupun sekunder dilakukan peneliti selama 6 bulan, selama masa pengabdian masyarakat tentang pelatihan kewirausahaan yang dilaksanakan pada BUMDes. Keterbatasan waktu dan situasi wabah pandemi, maka penulis juga menggunakan media online untuk memperoleh data, berikut juga wawancara secara mendalam. Penggalian informasi juga dilakukan terhadap masyarakat Desa Sukorejo melalui wawancara secara langsung oleh peneliti.

\section{HASIL DAN PEMBAHASAN}

\section{Pendekatan Bisnis BUMDes "Podho Joyo" Selama Pandemi Covid'19 \\ BUMDes "Podho Joyo" di Desa} Sukorejo adalah termasuk lembaga BUMDes yang berhasil mengelola potensi desa berbasis kearifan lokal. Terbukti dari kemampuan manajemen BUMDes yang dibangun sejak 5 April 2008, hingga pencapaian memperoleh penghargaan BUMDes terbaik Tahun 2016 dalam kategori tata kelola administrasi BUMDes. Unit bisnis yang dikelola oleh BUMDes sebelum masa pandemi meliputi:

1. Pasar Desa

2. Unit Simpan Pinjam

3. Perdagangan/ Toko

4. Jasa Pembayaran (Token) Listrik, Pulsa

5. Penjualan Pupuk Bersubsidi

6. Pengangkutan Sampah

Sebelum masa pandemi, bisnis BUMDes "Podho Joyo" menempatkan pemberdayaan unsur kearifan lokal dalam memberdayakan potensi desa. Kearifan lokal Desa Sukorejo memiliki keunggulan sumber daya manusia, yaitu sikap kekeluargaan dan kegotongroyongan. Sikap masyarakat akan membentuk perilaku kepemimpinan dan nilai - nilai organisasi yang baik terhadap pembentukan manajemen bisnis BUMDes. Sumber daya manusia bagi BUMDes merupakan modal sosial yang mampu mendukung "Podho Joyo" sebagai BUMDes berkemajuan.

Pendirian BUMDes "Podho Joyo" sesuai UU No. 32 Tahun 2004 merupakan usulan swadaya masyarakat Desa Sukorejo untuk meningkatkan jumlah PAD dengan permodalan sesuai prinsip pembentukan lembaga, yaitu $51 \%$ berasal dari dana desa dan 49\% dadalah penyertaaan modal. Awal pembentukan BUMDes adalah mengelola dana sebesar Rp 47 Juta dan aset yang dimiliki BUMDes "Podho Joyo" saat ini adalah sebesar kurang lebih Rp 5 Milyar dengan pendapatan rata - rata dari sebelum masa pandemi (Tahun 2019) adalah Rp 5 Juta per bulan. Pendekatan BUMDes sebelum masa pandemi juga mengadakan kerjasama dengan pihak perbankan dalam mendukung unit bisnis BUMDes. Pembentukan unit bisnis yang disediakan adalah menyesuaikan apa yang menjadi kebutuhan masyarakat Desa Sukorejo. 
Kearifan lokal Desa Sukorejo selaian dari modal sosial juga di dukung oleh potensi alam yang dimiliki oleh desa. Sebagian besar masyarakat bermata pencaharian sebagai petani dan beberapa wanita adalah pengusaha. Tujuan secara umum pada BUMDes adalah memenuhi kebutuhan desa dan menghindari permainan harga oleh para tengkulak, sedemikian juga diterapkan oleh BUMDes "Podho Joyo" yang bekerja sama dengan penduduk Desa Sukorejo sebagai pemasok produk BUMDes. Potensi pertanian Desa Sukorejo memiliki keunggulan yang didukung oleh ketersediaan sumber air yang memadai, sehingga kegiatan pertanian dapat dilaksanakan sepanjang tahun. Hasil pertanian mampu menopang ekonomi masyarakat desa. Di masa pandemi juga tidak mempengaruhi hasil pertanian Desa Sukorejo.

Meskipun hasil laporan kinerja ekonomi Jawa Timur berdasarkan Data Bank Indonesia menyatakan bahwa kinerja ekonomi beberapa daerah di Jawa Timur selama masa pandemi mengalami pelambatan, akan tetapi bagi Desa Sukorejo tidak terlalu berdampak. Terbukti dari pemasaran hasil pertanian Desa Sukorejo melalui BUMDes "Podho Joyo" menunjukkan pendapatan yang dihasilkan dari unit perdagangan berada pada nilai stabil. Selama masa pandemi, Desa Sukorejo juga sempat mengalami situasi di mana Pasar Sukorejo mengalami penutupan kurang lebih 1 sampai 2 bulan. Setelah penetapan new normal daerah, maka pasar desa dibuka seperti biasa. Pendapatan BUMDes secara rata - rata tidak mengalami penurunan signifikan di Tahun 2020,yaitu rata - rata pendapatan per bulan kurang lebih Rp 6 Juta. Kinerja ekonomi BUMDes "Podho Joyo" sempat sedikit berdampak kurang lebih pada pendapatan di bulan Maret dan April.

Pendekatan bisnis BUMDes "Podho Joyo" selama masa pandemi dibantu oleh dukungan pesanan melalui online dengan media "Whatsapp" dengan sistem pesan antar. Konsep bisnis BUMDes "Podho Joyo" sebelum masa pandemi sebenarnya sudah cukup mumpuni dengan tersedianya aplikasi belanja "Peken" untuk transaksi jual beli, tetapi pemanfaatannya masih belum termaksimalkan bagi masyarakat Desa Sukorejo, karena masyarakat masih memiliki kelemahan dalam "melek teknologi" melalui aplikasi. Selain itu pemeliharaan terhadap pemasaran digital dari pihak BUMDes "Podho Joyo" juga belum teroptimalisasi. Pola konsumsi masyarakat Desa Sukorejo masih lebih menyukai sistem konvesional dalam bertransaksi ekonomi. Kegiatan belanja masyarakat Desa Sukorejo pada Pasar Desa Sukorejo dilakukan pada pagi hari selama 2 jam (pukul 5-7 pagi).

Temuan di lapangan memberikan informasi bahwa aktivitas warga berbelanja tidak begitu berdampak selama masa pandemi. Unit usaha jasa pasar desa yang dikelola BUMDes "Podho Joyo" memiliki rekanan yang terus bertambah, dengan penyewaan stan tempat berjualan di pasar desa. Awal mula berdirinya BUMDes terdapat 70 pedagang, sampai saat ini dengan total jumlah rekanan penyewa Pasar Desa Sukorejo sebanyak 105 pedagang. Strategi bisnis BUMDes "Podho Joyo" untuk unit usaha sewa tempat pasar desa adalah klasifikasi jenias biaya sewa tempat yang berbeda pada masing - masing pedagang bergantung pada lokasi tempat berdagang. Biaya sewa tempat termahal ada pada fasilitas ruang petak pada Pasar Desa Sukorejo. Semakin tinggi harga sewa bila ruang petak semakin terfasilitasi.

Kenaikan jumlah pemasukan BUMDes "Podho Joyo" selama masa pandemi Covid'19 adalah pada unit usaha simpan pinjam. Jumlah peningkatan nasabah pada Tahun 2020 mencapai kenaikan sebanyak lebih dari 100 orang nasabah. Unit usaha simpan pinjam memiliki prospek dikembangkan pada BUMDes "Podho Joyo", karena bertambahnya jumlah nasabah. Mengacu pada Data Bank Indonesia bahwa kinerja keuangan rumah tangga Jawa Timur secara keseluruhan mengalami penurunan, termasuk masyarakat Desa Sukorejo. Perilaku masyarakat secara umum mengalami penurunan jumlah konsumsi akibat situasi pandemi, sementara pendapatan rumah tangga akibat dampak pandemi secara rata - rata juga mengalami penurunan.

Menurut data kinerja ekonomi Jawa Timur, terbukti juga bagi masyarakat Desa Sukorejo memanfaatkan tabungan dan pinjaman di tengah pelambatan ekonomi selama masa pandemi. Strategi bisnis yang dijalankan BUMDes "Podho Joyo" pada unit usaha BUMDes adalah ketersediaan program simpanan dana sebagai investasi tabungan dengan sistem bagi hasil. Pendekatan bisnis BUMDes "Podho Joyo" untuk unit simpan pinjam adalah menyediakan produk simpanan masyarakat yang dimaksudkan untuk 
memenuhi kebutuhan masyarakat pada aspek keuangan. Bentuk produk simpanan, antara lain meliputi:

a. Tabungan Umum (perorangan)

b. Tabungan Anak (siswa pelajar)

c. Tabungan Pendidikan

d. Tabungan Qurban

e. Deposito

sedangkan produk pinjaman BUMDes "Podho Joyo" terdistribusi menurut kelompok nasabah, yaitu:

a. Usaha Ekonomi Mikro: perdagangan, perindustrian, peternakan, jasa

b. Cadangan Pangan Pemerintah Desa: pertanian

c. Kredit Multi Guna: rumah tangga

Sebagai lembaga sosial, tetapi juga harus menjadi lembaga yang memberikan profit bagi lembaga, maka pengelolaann unit usaha simpan pinjam pada BUMDes "Podho Joyo" diterapkan prinsip - prinsip keuangan yang tidak memberatkan masyarakat Desa Sukorejo. Bahkan BUMDes "Podho Joyo" juga menyediakan beasiswa kuliah di perguruan tinggi bagi putra/putri Desa Sukorejo yang nantinya akan menjadi kader penerus BUMDes.

Unit usaha perdagangan pada BUMDes "Podho Joyo" adalah penyediaan bahan sembako, ATK serta makanan dan minuman tahan lama. Kearifan lokal Desa Sukorejo yang meliputi hasil pertanian, dikelola oleh wanita pengusaha Desa Sukorejo menjadi olahan produk makanan ringan yang dijual pada toko BUMDes. Selama masa pandemi, produk masyarakat Desa Sukorejo dari hasil pertanian tetap berproduksi dan tidak begitu terkena dampak wabah, karena pemasaran tetap berjalan, apalagi didukung Pasar Desa Sukorejo juga tetap beroperasi seperti sediakala. Selanjutnya untuk unit bisnis penjualan pupuk bersubsidi dari pemerintah adalah setiap musim BUMDes "Podho Joyo" mendapatkan jatah persediaan sebanyak 9 ton. Kuantitas pupuk bersubsidi mampu memenuhi kebutuhan petani terhadap pupuk untuk meningkatkan kualitas hasil pertanian milik warga Desa Sukorejo.

Pendekatan bisnis BUMDes "Podho Joyo" yang akan segera dikembangkan sebagai program kerja lanjutan BUMDes atas isu lingkungan sekaligus isu bisnis selama masa pandemi Covid'19 adalah pemberdayaan sampah. Unit bisnis pengangkutan sampah Desa Sukorejo, mencakup pengangkutan dan pembuangan sampah rumah tangga dan sampah pasar desa, sebelum masa pandemi adalah sudah dikelola oleh BUMDes, akan tetapi pengelolaan sampah untuk tujuan bisnis belum dikelola sebagai unit usaha BUMDes. Setelah menguraikan beberapa pendekatan bisnis yang dikelola oleh BUMDes dengan membandingkan antara strategi bisnis pada masa sebelum dan saat pandemi, maka dapat dianalisis bahwa selama masa pandemi, inovasi bisnis oleh "Podho Joyo" sebagai lembaga komersial Desa Sukorejo adalah tergolong proaktif, baik dilakukan oleh pemimpin, pengelola, maupun pengguna BUMDes.

Model bisnis yang dijalankan oleh BUMDes "Podho Joyo" telah sesuai menerapkan seluruh kriteria taksonomi "Kerangka Klasifikasi Proses" dari standar yang dimiliki oleh "Pusat Kualitas Produktivitas Amerika", di mana menggunakan indikator proses bisnis dengan mengukur dari kinerja antarorganisasi. Seluruh operasi proses bisnis BUMDes "Podho Joyo" telah melalui enam tingkat proses, seperti:

1. Pengembangan Visi dan Strategi

2. Pengembangan dan Pengelolaan Barang dan Jasa

3. Pemasaran dan Penjualan Barang dan Jasa

4. Pengiriman Barang

5. Pemberian Layanan

6. Pengelolaan Pelayanan terhadap Pelanggan

Selain itu BUMDes "Podho Joyo" juga telah menjalankan tujuh tingkatan terhadap manajemen dan layanan pendukung, yaitu:

7. Pengembangan dan Pengelolaan Sumber Daya Manusia)

8. Pengelolaan Teknologi Informasi)

9. Pengelolaan Sumber Daya Keuangan) Pengelolaan Sumber Daya Keuangan)

10.Memperoleh, Membangun dan Mengelola Aset)

11.Pengelolaan Risiko Usaha, Kepatuhan, Perbaikan, dan Ketahanan)

12.Pengelolaan Hubungan dengan Pihak Eksternal

13.Pengembangan dan Pengelolaan Kemampuan Usaha).

Kelemahan pada BUMDes "Podho Joyo" yang masih membutuhkan penguatan adalah pada proses di tingkat 8 sampai tingkat 13 agar nantinya dapat mempertahankan posisinya sebagai BUMDes berkemajuan di segala kondisi, walaupun mengalami masa pandemi. 


\section{Strategi Kewirausahaan Desa Sukorejo Selama Di Tengah Pandemi}

Pendekatan bisnis BUMDes "Podho Joyo" yang selama ini dijalankan tidak terlepas dari strategi kewirausahaan Desa Sukorejo, karena tanpa dukungan semua stakeholder, maka semua program tidak dapat berjalan. Salah satu bentuk strategi kewirausahaan Desa Sukorejo adalah mendukung pengembangan BUMDes "Podho Joyo" dari tata kelola konvensional menjadi tata kelola profesional. Perencanaan program BUMDes "Podho Joyo" Tahun 2021 sebagai manifestasi strategi kewirausahaan desa adalah memberdayakan potensi lokal desa, yaitu pengelolaan sampah yang selama ini belum dikembangkan menjadi potensi bisnis. Manajemen bank sampah Desa Sukorejo belum dikelola secara efektif, meskipun sumber daya manusia telah didelegasikan. Direktur BUMDes "Podho Joyo" menjelaskan bahwa pengelolaan bisnis berbahan sampah akan menjadi target realisasi unit bisnis baru bagi BUMDes.

Mengingat modal sosial sebagai potensi kearifan lokal Desa Sukorejo memiliki nilai kompetensi dalam mendukung kemajuan BUMDes, maka strategi kewirausahaan yang dilakukan adalah membuka peluang untuk menambah lapangan pekerjaaan dari BUMDes "Podho Joyo". Sebagai lembaga sosial, maka strategi kewirausahan BUMDes terhadap Desa Sukorejo adalah mengoptimalkan dana sosial dari keuntungan bisnis BUMDes "Podho Joyo" untuk mengadakan kegiatan berbagi dengan masyarakat desa, seperti program sosialisasi kebersihan oleh BUMDes ke sekolah dan program bantuan sembako kepada warga Desa Sukorejo yang memiliki keterbatasan ekonomi. Kewirausahaan masyarakat desa dapat digerakkan melalui strategi bisnis BUMDes "Podho Joyo" untuk mendayagunakan semua potensi desa demi menopang kesejahteraan masyarakat Desa Sukorejo.

Strategi kewirausahaan BUMDes "Podho Joyo" yang selama ini pernah dilakukan antara lain, seperti menstimulasi kemampuan masyarakat desa untuk menciptakan produk unggulan desa yang dilakukan dengan mengadakan kompetisi atau lomba membuat produk baru. Antusiasme masyarakat Desa Sukorejo cukup tinggi, karena stimulas dari kompetisi adalah pemberian kompensasi yang bernilai bagi para pemenang. Dalam rangka mendukung kemajuan BUMDes "Podho Joyo" dan meningkatkan nilai merek atas BUMDes serta mendukung kewirausahaan Desa Sukorejo, maka seringkali BUMDes "Podho Joyo" melibatkan diri dalam kegiatan pameran dan kompetisi di tingkat nasional. Beberapa program kewirausahan yang dilaksankan oleh BUMDes "Podho Joyo" selama ini telah mampu mendorong Kewirausahaan Desa Sukorejo untuk menggerakkan ekonomi desa. Kinerja ekonomi Desa Sukorejo mampu bertahan selama masa pandemi didukung oleh kewirausahaan desa dari masyarakat, sehingga pendekatan bisnis yang diimplementasikan melalui strategi bisnis BUMDes "Podho Joyo" dapat dioptimalkan secara berkesinambungan. Dukungan pemerintah Desa Sukorejo melalui bantuan penyertaan dana desa mampu menciptakan stabilitas kemajuan BUMDes "Podho Joyo".

\section{KESIMPULAN}

Dengan mendasarkan hasil penelitian ini dari pengamatan di lapangan pada BUMDes "Podho Joyo", maka dapat disimpulkan bahwa selama pandemi Covid'19, kinerja ekonomi Desa Sukorejo tidak mengalami keterpurukan ekonomi. Berbeda halnya bila dibandingkan dengan kondisi secara umumpada kinerja ekonomi Jawa Timur. Selama masa pandemi, Desa Sukorejo mengoptimalkan potensikearifan lokal desa, baik dari modal sosialnya maupun modal ekonominya yang berasal dari sumber potensi kekayaan khas desa, yaitu pertanian. Selain itu strategi kewirausahan Desa Sukorejo mampu menstimulus BUMDes "Podho Joyo" mengembangkan strategi bisnis di tengah pandemi. Kegiatan ekonomi di situasi "physical distancing dan lock down" hanya mengubah cara atau metode pendekatan bisnis BUMDes, akan tetapi tidak menggoyah mindset kewirausahaan masyarakat Desa Sukorejo. Dengan demikian dapat penulis sarankan bahwa melawan pandemi melalui inovasi dan kompetensi.

Keterbatasan akibat wabah pandemi boleh saja menghalangi gerak, namun tidak dapat membatasi ide atau gagasan untuk menggerakkan semangat kewirausahan untuk memanfaatkan potensi bisnis. Bagi peneliti yang konsentrasi dengan topik kewirausahan selanjutnya dapat dilakukan eksplorasi tentang bagaimana konsep bisnis berbahan sampah dapat menjadi potensi kearifan lokal Desa 
Sukorejo, sehingga mampu menambah pengetahuan kewirausahan dengan cara memberikan solusi mengatasi masalah lingkungan dengan solusi melalui bisnis dari penguatan potensi desa.

\section{DAFTAR PUSTAKA}

Ainiyah, N., \& Aprilia, R. D. R. (2020). Pelatihan Dan Pendampingan Pengelola Bumdes Dalam Rangka Optimalisasi Potensi Desa Di Desa Pungging Mojokerto. Abdimas Nusantara, 2(1), 1068-1076.

Anggraeni, M. R. R. S. (2016). Peranan Badan Usaha Milik Desa (BUMDes) Pada Kesejahteraan Masyarakat Pedesaan Studi Pada Bumdes Di Gunung Kidul, Yogyakarta. MODUS, 28(2), 155-167.

Brawijaya, P. F. U. (2007). Pendirian dan Pengelolaan Badan Usaha Milik Desa (BUMDes): Departemen Pendidikan Nasional Pusat Kajian Dinamika Sisitem Pembangunan ....

Budiono, P. (2015). Implementasi Kebijakan Badan Usaha Milik Desa (Bumdes) Di Bojonegoro (Studi di Desa Ngringinrejo Kecamatan Kalitidu Dan Desa Kedungprimpen Kecamatan Kanor). Jurnal Politik Muda, 4(1), 116125.

Hanafi, M. (2015). Community-Based Research Panduan Perencanaan Dan Penyusunan Proposal CBR Universitas Islam Negeri Sunan Ampel Surabaya: LP2M UIN Sunan Ampel Surabaya.

Hidayat, A., \& Sulastri, L. (2019). Empowerment Strategy of Village Enterprises Unit (VEU) to Improve Capacity and Their Performances in Sumedang Regency. European Journal of Sustainable Development, 8(4), 315324.

Kusuma, G. H., \& Purnasari, N. (2016). BUMDes: Kewirausahaan Sosial Yang Berkelanjutan. Yogyakarta, Yayasan Penabalu.

Maab, M. H., Wijaya, S. S., Atika, Z. R., \& Kurniasih, D. (2018). RETHINKING MODEL BISNIS PEMERINTAH DESA: KASUS PADA BADAN USAHA MILIK DESA DI
KABUPATEN BANYUMAS, INDONESIA. Jurnal Litbang Provinsi Jawa Tengah, 16(1).

Mulatsih, S., \& Purnamadewi, Y. L. (2020). PEMILIHAN UNIT USAHA BUMDES HARAPAN JAYA SESUAI DENGAN POTENSI LOKAL DI DESA PAGELARAN. Jurnal Benefita: Ekonomi Pembangunan, Manajemen Bisnis \& Akuntansi, 5(1), 101-112.

Nassaji, H. (2015). Qualitative and descriptive research: Data type versus data analysis: Sage Publications Sage UK: London, England.

Nilawati, E. (2018). Analisis Manajemen Badan Usaha Milik Desa (BUMDESA)“Hanyukupi” Desa Ponjong Kecamatan Ponjong Kabupaten Gunungkidul. Jurnal Wacana Kinerja, 21(1), 49-72.

Purabaya, R. H., Pradnyana, I. W. W., \& Wahyono, B. T. (2020). Model Arsitektur Proses Bisnis Badan Usaha Milik Desa dengan Menggunakan Process Classification Framework (Studi Kasus: Badan Usaha Milik Desa "Cahaya Buana Paku Banten", Desa Sukatani, Kecamatan Cikande, Kabupaten Serang). Informatik: Jurnal Ilmu Komputer, 15(2), 103-112.

Raco, J. (2018). Metode penelitian kualitatif: jenis, karakteristik dan keunggulannya.

Ramadana, C. B. (2013). Keberadaan Badan Usaha Milik Desa (BUMDES) sebagai Penguatan Ekonomi Desa. Jurnal Administrasi Publik, 1(6), 1068-1076.

Scarborough, N. M. (2015). Entrepreneurship and effective small business management: Pearson Higher Ed.

Sumantara, K., Suryani, K., Widnyana, I. W., Menes, C. C., Sutrisna, I. P., Oktariana, O., \& Dana, R. S. (2019). Swot Analysis Of Village Owned Enterprises (Bumdes) Trading Business Of" Ayu Bagia" Goods In Baha VillageKecamatan Mengwi Badung DistrictBali. INTERNATIONAL JOURNAL OF SUSTAINABILITY, EDUCATION, AND GLOBAL CREATIVE ECONOMIC (IJSEGCE), 2(1), 15-20.

Thaha, A. F. (2020). DAMPAK COVID-19 TERHADAP UMKM DI INDONESIA. BRAND Jurnal Ilmiah Manajemen Pemasaran, 2(1), 147-153. 
Zulkarnaen, R. M. (2016). Pengembangan potensi ekonomi desa melalui badan usaha milik desa (bumdes) pondok salam kabupaten purwakarta. Dharmakarya, 5(1).

https://www.bi.go.id/id/publikasi/kajian-

ekonomi-regional/laporan-

nusantara/Pages/Laporan--

Nusantara_Mei_2020.aspx. 